\title{
Nucleotide excision repair and photolyase preferentially repair the nontranscribed strand of RNA polymerase III-transcribed genes in Saccharomyces cerevisiae
}

\author{
Abdelilah Aboussekhra and Fritz Thoma ${ }^{1}$ \\ Institut für Zellbiologie, Swiss Federal Institute of Technology (ETH)-Zürich, Hönggerberg, CH-8093 Zürich, Switzerland
}

\begin{abstract}
A high-resolution primer extension technique was used to study the relationships between repair, transcription, and mutagenesis in RNA polymerase III transcribed genes in Saccharomyces cerevisiae. The in vivo repair of UV-induced DNA damage by nucleotide excision repair (NER) and by photoreactivation is shown to be preferential for the nontranscribed strand (NTS) of the SNR6 gene. This is in contrast to RNA polymerase II genes in which the NER is preferential for the transcribed strand (TS). The repair-strand bias observed in SNR6 was abolished by inactivation of transcription in a snr6 22 mutant, showing a contribution of RNA polymerase III transcription in this phenomenon. The same strand bias for NER (slow in TS, fast in NTS) was discovered in the SU P4 gene, but only outside of the intragenic promoter element (box A). Unexpectedly, the repair in the transcribed box A was similar on both strands. The strand specificity as well as the repair heterogeneity determined in the transcribed strand of the SU P4 gene, correlate well with the previously reported site- and strand-specific mutagenesis in this gene. These findings present a novel view regarding the relationships between DNA repair, mutagenesis, and transcription.
\end{abstract}

[Key Words: Cyclobutane pyrimidine dimers; nucleotide excision repair; photoreactivation; RN A polymerase III transcription; SNR6; Saccharomyces cerevisaie]

Received July 25, 1997; revised version accepted N ovember 13, 1997.

UV light is an efficient DNA damaging agent, mainly responsible for the formation of pyrimidine dimers (PDs). These lesions are mostly eliminated by photoreactivation (PR) and/or nucleotide excision repair (NER) (Friedberg et al. 1995). The first process is a direct unistep DNA repair mechanism that reverses cyclobutane pyrimidine dimers (CPDs) by reversing the linkage between the adjacent pyrimidines with a light-initiated electron transfer reaction (Sancar 1990, 1996b; Wood 1996). It was shown recently that the PR of active genes is modulated by chromatin structure and transcription (Livingstone-Zatchej et al. 1997; Suter et al. 1997). The Saccharomyces cerevisiae photolyase preferentially repairs the nontranscribed strands (NTSs) of RNA polymerase II (RN AP II)-transcribed genes, whereas the PR of the transcribed strand (TS) is inhibited by a stalled RN A polymerase (Livingstone-Zatchej et al. 1997; Suter et al. 1997). This provides an explanation for the previous observation that the photorepair of the Escherichia coli ga-

${ }^{1}$ Corresponding author.

E-MAIL thoma@cell.biol.ethz.ch; FAX 4116331069. lactokinase-forming capacity is inhibited when the gene is transcriptionally active (Kolsch and Starlinger 1965).

The NER is a multistep mechanism that copes with a large range of DNA damage including CPDs (Sancar 1996a; Wood 1996). During the last decade, a link was observed between the NER process and transcription. It is clear that the transcriptionally active genes are more rapidly repaired and that their TSs are preferentially repaired (Hanawalt 1995; Friedberg 1996a,b; Sancar 1996a). NER and transcription are linked in two different ways:

First, the presence of specific cellular factors assures preferential repair of the template strands of active genes. In E. coli, this process is known as transcriptioncoupled repair (TCR) and is under the control of the mfd gene product also called TRCF (transcription repair coupling factor) (Sel by and Sancar 1993, 1994). In human and S.cerevisiae cells, the strand-specific repair of active genes requires the products of CSA and CSB/RAD26 genes (Bhatia et al. 1996), however, the bi ochemical coupling of transcription and repair has not been shown as yet.

The second connection is the dual function of TFIIH components in transcription and NER (Feaver et al. 
1993; Drapkin et al. 1994; Wang et al. 1994; Svejstrup et al. 1995; Friedberg 1996b). The role of TFIIH in connecting these two processes is still puzzling because it is only involved in promoter clearance (Goodrich and Tjian 1994) and seems to dissociate from the elongating RN AP II machinery once the nascent transcript becomes longer than $\sim 30$ nucl eotides (Zawel et al. 1995). The high TFIIH affinity for the RNAP II complex, however, may play a role in rapid loading of the NER apparatus on the damaged site in the vicinity of a stalled RNAP II (Chal ut et al. 1994). Does strand-specific repai $r$ of active genes only concern the RNAP II-transcribed genes?

It is well known that in addition to RN AP II, the transcription of eukaryotic genomes requires RNAP I and RNAP III, which transcribe different sets of genes (Zawel and Reinberg 1995). RN AP III is responsible for the transcription of several cellular and viral RNAs. Most RNA transcribed by RNAP III correspond to very short transcription units that are extensively covered with transcription factors binding to intragenic promoter elements. The genes transcribed by RN AP III fall into three different classes depending on the promoter structures and their cognate transcription factors. RNAP III involves the accessory transcription factors TFIIIA, TFIIIB, and TFIIIC, which interact with the promoter elements (A, B, and C boxes) to form a stable preinitiation complex (Hernandez 1993; Geiduscheck and Kassavetis 1995; Zawel and Reinberg 1995).

The first and second cl ass promoters are intragenic and TATA boxless, and could be exemplified by the 5S RN A and tRN A gene promoters. In both classes of promoters, the binding of TFIIIC is followed by the recruitment of TFIIIB that can directly contact RN AP III and initiates several rounds of transcription (Hernandez 1993; Geiduscheck and Kassavetis 1995; Zawel and Reinberg 1995).

The U 6 snRN A exemplifies the third class of RN AP III transcribed genes. The yeast SNR6 promoter contains a canonical TATA box at -30 , an internal degenerate box $A$ at +21 and a downstream box $B$ at 202 bp from box $A$ (Brow and Guthrie 1990). SNR6 is an essential gene coding for a nontranslated small RNA involved in RNA splicing in yeast and human cells (Brow and Guthrie 1988, 1990). A 2-bp deletion at the B box dramatically inhibits the SNR6 transcription and alters the nucleosome arrangement in the flanking regions ( $M$ arsolier et al. 1995).

The relationship between excision repair of RNAP III genes and their transcription has not been explored in depth. It was stated in a recent report that, in human cells, the transcription by RNAP III of tRNA ${ }^{\mathrm{Sec}}$ and tRNA ${ }^{\vee a l}$ genes is uncoupled to NER (Dammann and Pfeifer 1996). In S. cerevisiae, however, the tRN A suppressor gene SU P4-o showed a preferential mutation induction occurring at sites in which the dipymidine was on the TS (Armstrong and Kunz 1990). This might be explained by a possible transcription of the NTS by RNAP II from a cryptic promoter within the plasmid vector used in that study (Armstrong and Kunz 1995). Alternatively, the strand preferential mutagenesis could imply a repair strand bias in the S. cerevisaie RN AP III transcribed genes. To investigate this question, a detailed analysis is required.

In this study, a high-resolution technique was used to investigate the effect of transcription on the repair of UV-induced DNA damage in two different RNAP IIItranscribed genes, SU P4 and SNR6. We report a preferential repair of the NTS of the SNR6 gene by both NER and PR. This strand bias of NER and PR was abol ished by transcriptional inactivation of the SNR6 gene, showing the contribution of the transcription by RNAP III in this strand-specific repair. Moreover, the same strand bias was observed by analysis of NER in the SU P4 gene. Surprisingly, the nucleotide excision repair in the SU P4 intragenic promoter element box A was not strand specific. These results provide important insight into the mechanisms relating DN A repair to transcription.

\section{Results}

DNA repair analysis at nucleotide resolution of UV-induced DNA damage

In this study, a primer extension assay was used to investigate the repair of photodimers formed in yeast genomic DN A. Yeast cells were UV-irradiated in suspension in water with $200 \mathrm{~J} / \mathrm{m}^{2}$. At this UV dose, $\sim 0.3 \mathrm{PD}$ is formed in each kilobase and up to $40 \%$ of the cells survive. The irradiated cells were then reincubated for different repair times, either in a growth medium, under yellow light at $30^{\circ} \mathrm{C}$ to allow nucleotide excision repair (dark repair, from 0 to $4 \mathrm{hr}$ ), or in water under the photoreactivating light (predominantly at $366 \mathrm{~nm}$ ) (from 0 to $1 \mathrm{hr}$ ). The UV-damaged and repaired genomic DN A were purified, cut with EcoRI, denatured, and annealed to appropriate radiolabeled primers. PDs were then mapped by primer extension with Taq polymerase. Efficient blockage of Taq polymerase elongation occurs almost exclusively at PDs, producing radiolabeled DNA fragments of different sizes (Wellinger and Thoma 1996). Once separated on a polyacrylamide gel, these fragments give rise to different bands representing the PD positions. The intensities of these bands at the repair time $(0$ $\mathrm{hr}$ ) correspond to the frequency of PD formation at particular sites. The repair is visualized by a timedependent decrease in the intensities of these different bands (Fig. 1A, lanes 1-5). Genomic DN A purified from nonirradiated cells was used both for DN A sequencing by use of the same primers, al lowing a precise localization of PDs, and as a control for nonspecific Taq polymerase bl ockage (Fig. 1A, lane 6). This sensitive and direct technique is apropos for investigating the PD formation and repair at high resolution in any region of $\mathrm{S}$. cerevisiae genomic DNA, in particular, when the region to be analyzed is short.

The NTS of the SUP4 gene is preferentially repaired by NER, but only outside of the intragenic promoter element box $A$

To investigate nucleotide excision repair in RNAP III genes, the strain FTY 113 was UV-irradiated and reincu- 
A

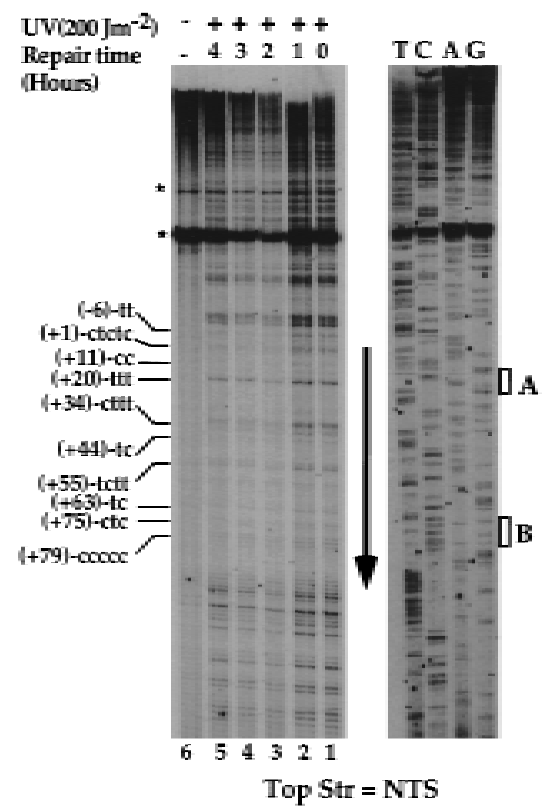

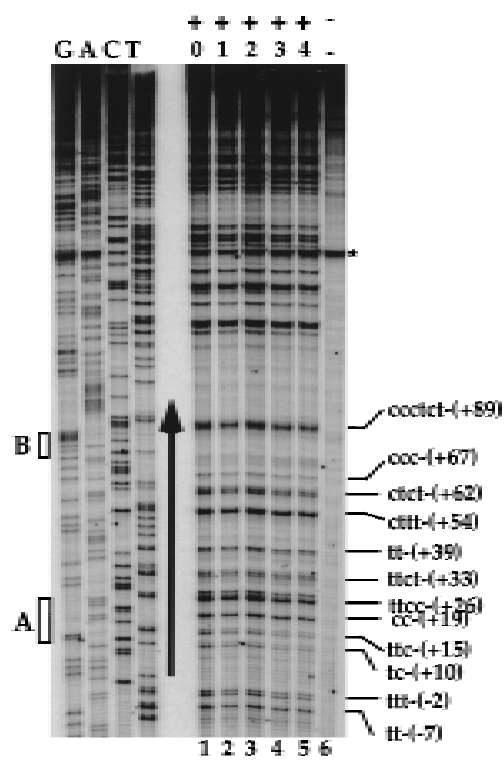

Botttom Str $=$ TS

\section{B}

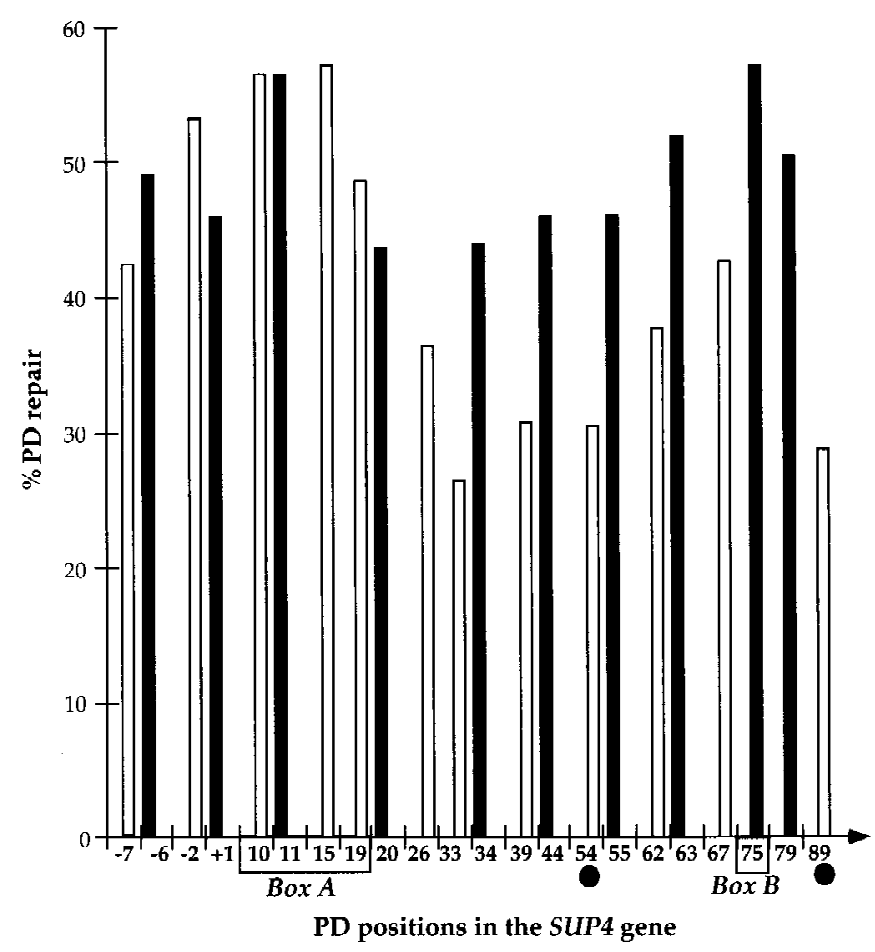

bated at $30^{\circ} \mathrm{C}$ for dark repair, and the genomic DN A was isolated at different repair times. The SU P4 gene, coding for a tRN $A^{T y r}$ was chosen for this aim because it is a well-studied RNAP III gene. SUP4 contains the intragenic promoter el ements A and B but lacks a TATA box (Knapp et al. 1978). DN A repair of the SU P4 gene was then investigated by primer extension. A detailed analy-
Figure 1. High-resolution analysis of nucl eoti de excision repair in the SU P4 gene. Yeast cells were UV-irradiated with $200 \mathrm{~J} / \mathrm{m}^{2}$ and reincubated under yellow light for the indicated repair times. PD repair was analyzed by primer extension. (A) Primer extension products in the TSs and NTSs. UV-irradiated DNA (lanes 1-5), nonirradiated DN A (lane 6), DN A sequencing (lanes $T, C, A, G)$. The letters on the left and the right sides represent pyrimidine clusters; the numbers refer to the $5^{\prime}$ nucleotide of the pyrimidine cluster in the SU P4 gene sequence (Knapp et al. 1978). Asterisks indicate nonspecific Taq polymerase arrests; (arrows) transcribed part; (boxes) the intragenic promoter elements box A and B. The top strand is NTS; the bottom strand is TS. (B) Quantitative analysis of PD removal from SU P4 TSs and NTSs. The fraction of PDs (\%) removed after $4 \mathrm{hr}$ from the TS (open bars) and NTS (solid bars). The numbers on the $x$-axis represent the positions of PD clusters. ( $)$ Hot spot of mutagenesis determined previously (Armstrong and Kunz 1990). The arrow indicates the direction of transcription. The data are averages of two experiments.

sis of the autoradiographs indicated a generally faster removal of the lesions formed in the NTS (Fig. 1A, top strand) compared with those of the TS (Fig. 1A, bottom strand). Figure $1 \mathrm{~B}$ shows quantitative results after $4 \mathrm{hr}$ of dark repair. The repair of the lesions formed in the NTS seems more homogeneous, with repair levels of $\sim 50 \%$. On the other hand, the excision repair on the TS appears 
more heterogeneous, depending on the position of the lesions in the gene (Fig. 1B). In box A, the lesions were removed with a rate similar to that of the lesions formed in the NTS, and in the upstream nontranscribed promoter region, $\sim 50 \%$ in $4 \mathrm{hr}$. In contrast, the photodimers formed in the TS, outside of box A, were more slowly repaired around $35 \%$ (ranging from $28 \%$ to $42 \%$ ). Thus, in this part of the gene, and unlike RNAP II genes, NER seems to be preferential for the NTS. These results show a site- and strand-specific repair in concordance with the high and site-specific mutagenesis found in the TS of the SU P4-o gene (Armstrong and Kunz 1990).

The NTS of the SN R6 gene is preferentially repaired by NER

The NTS-specific repair observed in the SU P4 gene was unexpected based on the well-established preferential repair of RNAP II TSs. To test whether this observation could be extended to other types of RN AP III transcribed genes, NER was investigated in the SNR6 gene. Figure $2 \mathrm{~A}$ indicates a faster decrease in the intensities of the bands in the NTS (top strand) compared with those in the TS (bottom strand). This observation was substantiated by Phosphorlmager quantification of the different bands of these gels, taking into account the loading differences (see $M$ aterials and $M$ ethods). DN A repai is presented in Figure $2 \mathrm{~B}$ as repair averages of all the PDs removed from the TS and NTS, respectively. Figure 2B shows a more efficient excision repair of the NTS. During $2 \mathrm{hr}$ of dark repair, $40 \%$ of the PDs were removed from the NTS, whereas only $20 \%$ was removed from the TS. After $4 \mathrm{hr}$ of repai r, $70 \%$ of the lesions were excised from the NTS, but only $35 \%$ were removed from the TS. Compared with the SU P4 gene, a slightly higher repair was noticed in the NTS of the SNR6 gene. Site-specific repair is shown for $4 \mathrm{hr}$ (Fig. 2C). The repair rates at individual sites in each individual strand were similar, with a slight decrease toward the $3^{\prime}$ end of the gene in both strands (Fig. $2 \mathrm{C}$ ). This figure also shows that the repair strand bias concerns all the PDs formed al ong the SNR6 gene. The SNR6 and SU P4 results together show that the preferential repair of the NTS is not gene specific, suggesting that the reduced repair rate in the TSs could be general for the RNAP III transcribed genes. It implies a role of RN AP III transcription in this phenomenon.

The preferential repair of the NTS in the SNR6 is dependent on RNAP III transcription

To test whether the slow repair of the SNR6 TS is the result of transcription by RNAP III, repair was analyzed in the FTY 115 strain in which the transcription of the SNR6 gene was abolished by a 2-bp deletion in the box $B$ (snr6 2 2). Because the SNR6 gene is essential for cell survival, the FTY 115 cells contain a pl asmid bearing a wildtype copy of the gene (M arsolier et al. 1995). Primers that allow for analysis of the genomic snr6 2 mutant were used (Marsolier et al. 1995). In the $\Delta 2$ mutant, the PDs seem to be removed with similar kinetics from both snr6 22 strands (Fig. 3A). Quantitative results showed that $\sim 50 \%$ of the lesions were excised after $4 \mathrm{hr}$ of repair (Fig. 3B). The lesions formed in the TS were repaired more efficiently in the snr6 22 mutant $(50 \%)$, in which SNR6 is transcriptionally inactive (Fig. 3B), than in the wild-type cells (35\%; Fig. 2C). In both strands of the nontranscribed snr6 22 gene, the repai $r$ rate was intermedi ate between the repair rates of the TS and NTSs of the wildtype SNR6 gene (Fig. 3B). This indicates that the inactivation of RN AP III transcription abolished the difference in repair rates observed between the TSs and NTS of the SNR6 gene. These data show a role of the transcription by RNAP III in the repair strand bias observed in the wild-type SNR6 gene and el iminate any hypothetical effect of DNA sequence in this phenomenon.

\section{RAD1 gene deletion abolishes the repair of the SN R6 gene}

To see whether the repair inhibition observed in the TS of SNR6 concerns the NER process or another DN A metabolism process, the RAD1 gene that codes for a component of the NER $5^{\prime}$ endonuclease Radlp/Rad10p (Wood 1996) was deleted in the FTY113 and FTY 115 strains constructing the strains $A A Y 1$ and $A A Y 2$, respectively. The rad1 $\triangle$ cells were UV-irradiated and reincubated for repai $r$ in the dark. The damaged genomic DN A was purified and the repair in the SNR6 gene was analyzed by primer extension. The results presented in Figures 4 and 5 show that PDs formed in both strands of the SN R6 gene persisted during the $2 \mathrm{hr}$ of incubation (Fig. 4 and 5, cf. lanes 1 and 5). The quantitative analysis of these gels confirmed that $<10 \%$ of the dimers were removed from each strand of the gene (Fig. 4B). A similar result was obtained after $4 \mathrm{hr}$ of incubation (data not shown). This shows that the repair of the RN AP III SNR6 gene is RAD 1-dependent, and thereby, the observed preferential repair of the NTS was carried out by NER.

The NTS of the SN R6 gene is preferentially repaired by photolyase

It was discovered previously that photolyase preferentially repairs the NTS of transcribed RNAP II genes, whereas the TS is sl owly repai red (Suter et al. 1997). To study the photorepair of a RNAP III gene and to see whether the preferential repair of the SNR6 NTS is confined to the N ER mechanism or can be extended to other DN A repair processes, the PR process was studied in the SNR6 gene. AAY 1 strain ( $\operatorname{rad} 1 \Delta)$ in which N ER was abolished by deletion of the RAD1 gene was used. The cells were UV-irradiated in suspension in water at a dose of $200 \mathrm{~J} / \mathrm{m}^{2}$ and then exposed to the photoreactivating light for 15,30 , and $60 \mathrm{~min}$. As a control, one al iquot of UVirradiated cells was incubated in the dark. DN A was isolated, treated as described previously, and the PD repair was analyzed by primer extension. The results presented in Figure 4 reveal a preferential photorepair of the NTS. As for NER, most of the CPDs formed in the NTS were 

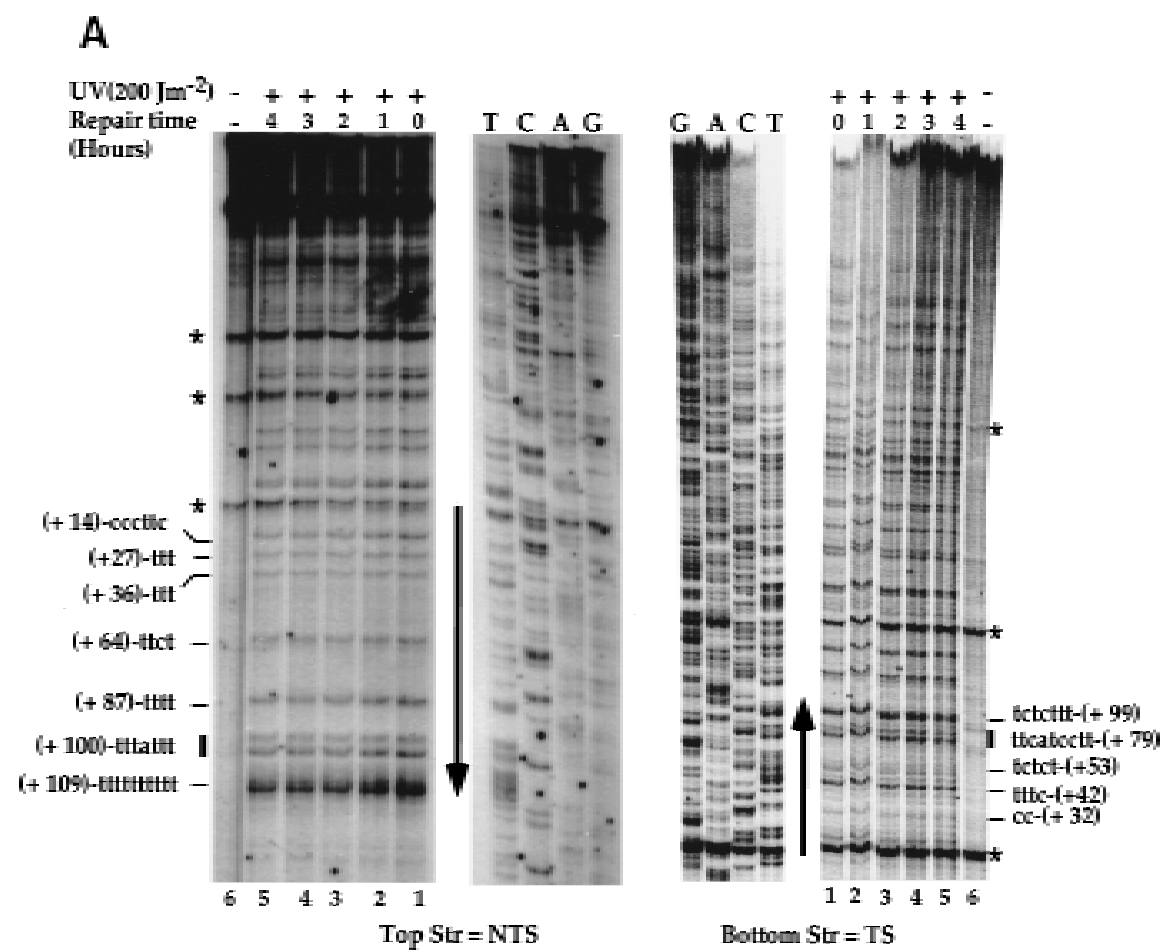

\section{B}
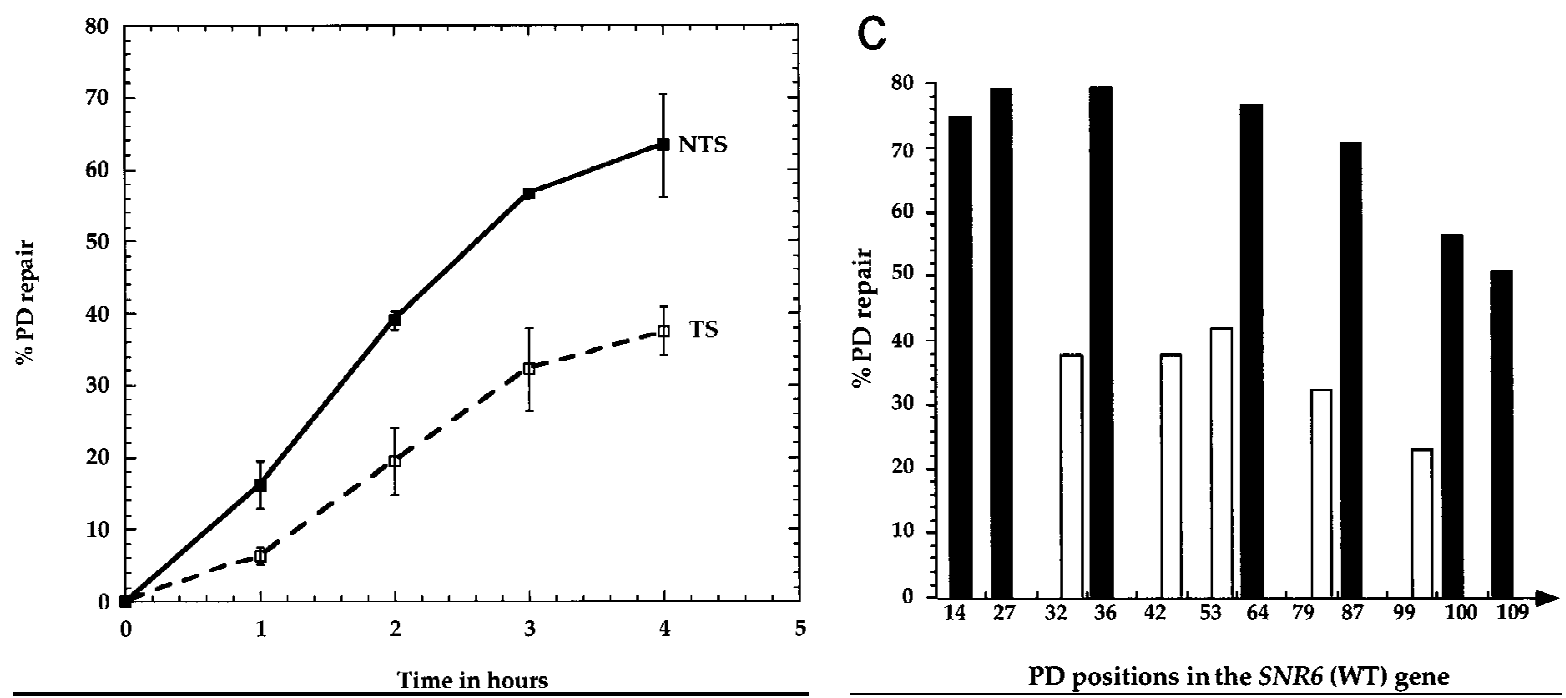

Figure 2. High-resolution analysis of nucleotide excision repair in the SNR6 gene. DNA was used as in Fig. 1. (A) Primer extension reactions on the TSs and NTSs. The legends are as in Fig. 1A. Indicated are pyrimi dine clusters (the numbers refer to the 5' nucl eotide in the SNR6 gene; Marsolier et al. 1995); pyrimidine clusters separated by a purine (solid bars); nonspecific Taq polymerase arrests (asterisks); the transcribed part (arrow). The top strand is NTS; the bottom strand is TS. (B) Quantitative analysis of PD removal in the TSs and NTSs. Represented is the fraction of PD (\%) removed from each strand at each repair time. Each data point corresponds to an averaged value of all the PDs removed from the transcribed part of the gene in the TS ( $\square$ ) and NTS ( $\square$ ), respectively. A verages with standard deviations of three experiments are shown for NTS (line) and TS (broken line). (C) Site-specific removal of PD after 4 hr of NER is shown. The numbers on the x-axis represent the PD positions in the SNR6 gene. (Open bars) TS; (solid bars) NTS. The arrow indicates the direction of transcription.

more rapidly repai red than those formed in the TS. In the dark, no repair was detected (Fig. 4A, lane 5), indicating that the repair observed is light dependent. The quantitative analysis of DNA repair is represented in Figure 4B.
Each data point represents an average of all the CPDs formed in each strand, respectively. During the first 15 min of repair, $20 \%$ of CPDs were repai red from the TS, whereas up to $40 \%$ were photoreversed from the NTS. 
A
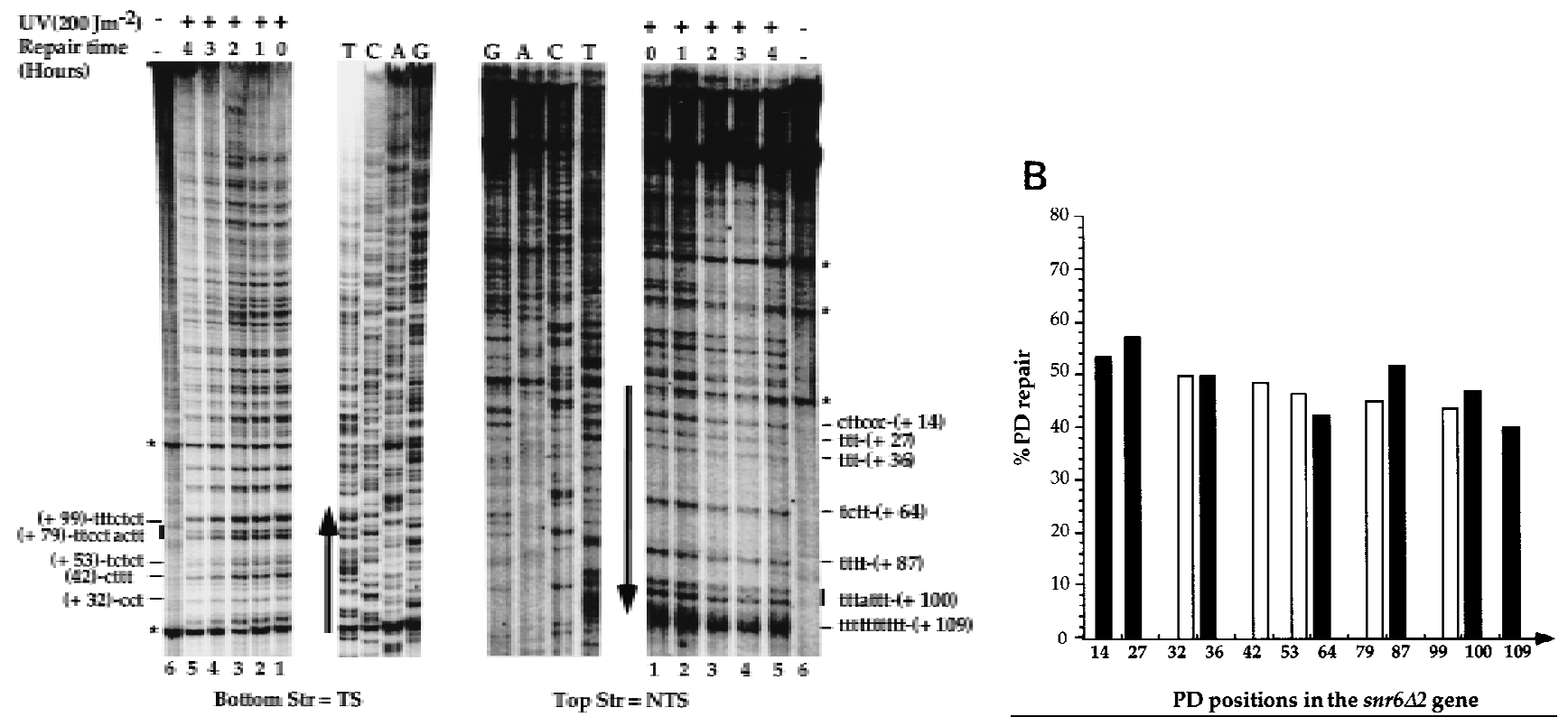

Figure 3. Repair analysis of pyrimidine dimers formed in the transcriptionally silent snr6 22 gene. snr6 22 mutant cells were treated as described in Fig. 1. (A) The same primers were used for primer extension in the top strand (NTS) and in the bottom strand (TS). (B) PD repair after $4 \mathrm{hr}$. (Open bars) TS; (solid bars) NTS. (See legend to Fig. 1 for details.)

After 60 min of repair, $>80 \%$ of CPDs were repaired from the NTS, but only $\sim 65 \%$ were repaired from the TS. Hence, PR, as well as NER, are both slower in the TS of the SNR6 gene. Because the PR is a very rapid process (Suter et al. 1997), the repair difference observed is more pronounced during the first $15 \mathrm{~min}$. In addition, the results show that photolyase has the same strand bias in RNAP II (Suter et al. 1997) and RN AP III genes.

The NTS-specific photorepair is dependent on transcription by RNAP III

To investigate the relationships between photorepair and RNAP III transcription, the AAY2 strain $(\operatorname{rad} 1 \Delta$, snr6 $\Delta 2$ ) in which the genomic snr6 $\Delta 2$ is transcriptionally silent, was used. AAY 2 cells were UV-irradiated under the same conditions as the AAY 1 cells, and reincubated for photorepair from 0 to $60 \mathrm{~min}$. The time course analysis of the PR presented on Figures $4 \mathrm{~B}$ and 5 show that both snr6 $\Delta 2$ strands are repaired with similar rates. Approximately $40 \%$ of CPDs were photoreactivated from both strands of the gene after $15 \mathrm{~min}$ under the photoreactivating light. Thus, the photorepair rate of both strands was similar to that obtai ned for the NTS of the transcriptionally active SNR6, but two-fold higher than that of the TS (Fig. 4B). This shows that the photorepair of the TS is more efficient in the absence of transcription. After $60 \mathrm{~min}$ of repair, $70 \%$ of CPDs were photoreversed in both strands of the silent snr6 $\Delta 2$ gene. For the samples incubated in the dark, $<10 \%$ of the lesions were repaired (Fig. 4B). This result shows that the photorepair-strand bias observed in the wild-type SNR6 gene is abolished when the transcription is inactivated by a mutation, indicating that the strand bias of PR in the wild-type SNR6 gene is dependent on transcription by RNAP III.

\section{Discussion}

The NTSS of RNAP III genes are preferentially repaired by NER and PR

It is shown in this study that in yeast $\mathrm{S}$. cerevisiae and in contrast to RN AP II transcribed genes, the RN AP III TSs are more slowly repaired by NER and PR than the NTSs. This phenomenon was discovered in two genes belonging to different RNAP III subclasses, SNR6 and SUP4 (Figs. 1 and 2). These results present the first example of a preferential repair of the NTS by NER. Hence, two different repair pathways show preferential repair of the NTS of a gene transcribed by RNAP III. What could be the cause of this phenomenon?

The NTS-specific repair is RNAP III transcription dependent

Because the strand bias for NER has been shown in two different genes, it can be excluded that the strand-specific repair results from a sequence difference between the two strands of these genes. Moreover, the results presented in Figures 3, 4, and 5 showed that the inhibition of SNR6 transcription led to similar excision repair and PR efficiencies in the TSs and NTSs of this gene. These data constitute a solid indication toward a role of 
RNAP III transcription and DNA repair

A

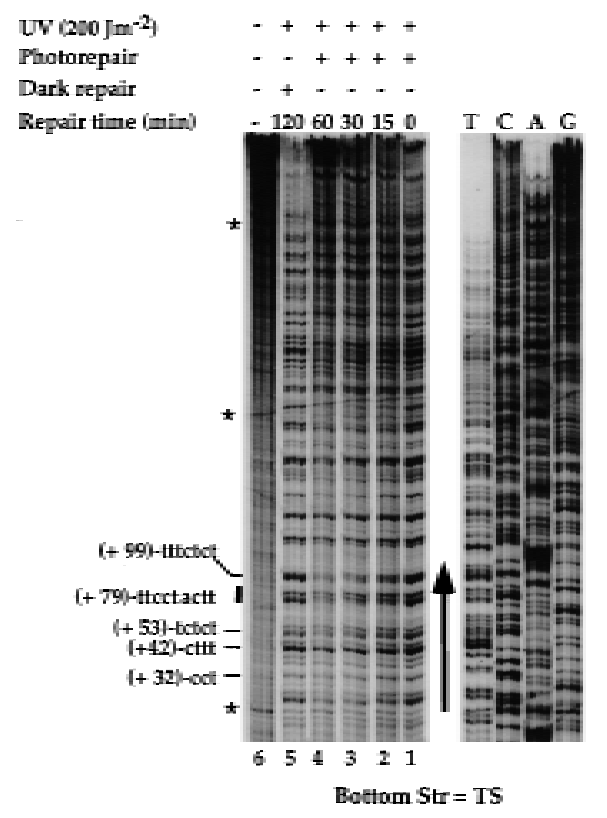

B

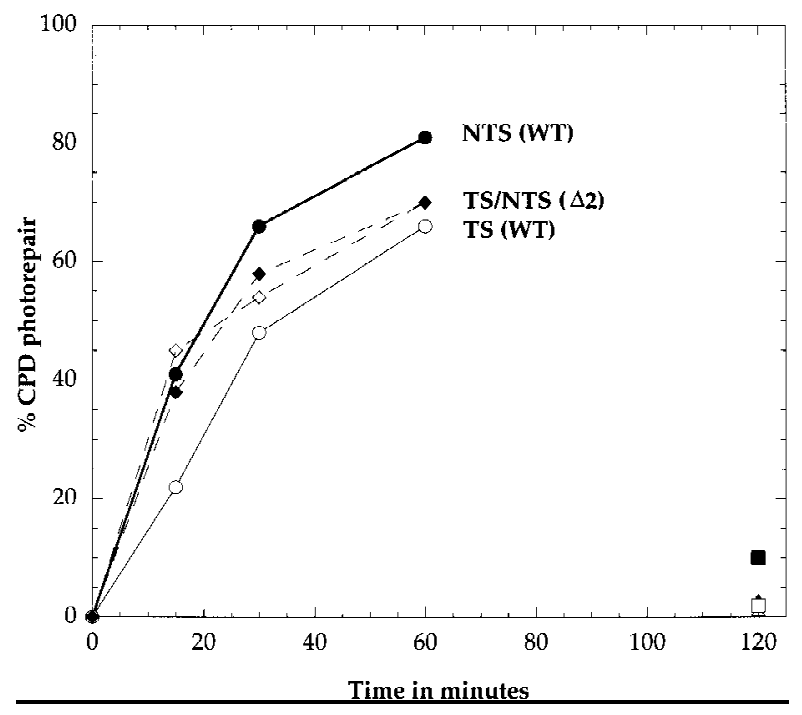

Figure 4. Repair of the SNR6 gene by photolyase. AAY $1(\operatorname{rad} 1 \Delta)$ cells were UV-irradiated with $200 \mathrm{~J} / \mathrm{m}^{2}$ and exposed to photoreactivating light for different times as indicated (lanes 1-4). As a control, an aliquot was kept in the dark for $2 \mathrm{hr}$ (lane 5) and another al iquot was not irradiated (lane 6). DNA was extracted, and CPD repair was analyzed by primer extension. (A) The legends are as for Fig. 1A. (B) Quantitative analysis of CPD repair in SNR6 and snr6 42 . The CPD fraction (\%) repaired at each time was determined as a repair average of all the CPD formed in the TS and in the NTS of SNR6 (line) and snr6 22 (broken line); values are averages of two primer extension experiments. TS (Open symbols); NTS (solid symbols); PR (diamonds and circles); N ER of Snr6 2 (squares); NER of SNR6 (triangles); triangles and squares overlap.

transcription by RN AP III in the repair-strand bias, and rule out the dependency of this phenomenon on DNA sequence. A plausible explanation for this preferential repair of the NTS is that the RNAP III, like the RN AP II, could be arrested in vivo by a UV-induced DNA damage in the TS (Donahue et al. 1994; Selby et al. 1997). The arrested RNAP III may cover the lesion, delaying the repair processes either by NER or by PR in the TS. For the NER process, this hypothesis implies that RNAP III is not connected to the N ER machinery neither by TFIIH [which is not required for RNAP III transcription (Geiduscheck and Kassavetis 1995)] nor by strand-specific repair factors. For RNAP II genes, Rad26p and CSA/CSB are good candidates for having the role of the $\mathrm{E}$. coli

TRCF, respectively, in $\mathrm{S}$. cerevisiae and human cells (Friedberg 1996b) - the role being to accel erate the excision repair of the TS, which allows the RNAP II to resume transcription rapidly. In the absence of these links between transcription and repair, even RN AP II TSs became repaired slowly. It was shown recently that PR preferentially repairs the NTSs of the three RNAP II genes, URA 3, HIS3, and GAL10 (Livingstone-Zatchej et al. 1997; Suter et al. 1997). This strand bi as is dependent on RNAP II transcription (Livingstone-Zatchej et al. 1997). Moreover, RN AP I (Vos and Wauthier 1991; Christians and Hanawalt 1993; Fritz and Smerdon 1995) and RN AP III (Dammann and Pfeifer 1996) transcription in mammalian cells was shown not to be connected to 
Figure 5. Analysis of the PR in the transcriptionally silent snr6 $\Delta 2$ gene. AAY2 $(\operatorname{rad} 1 \Delta, \operatorname{snr} 6 \Delta 2)$ was treated as the AAY1, and the repair experiment was performed as described in Fig. 4A (A).
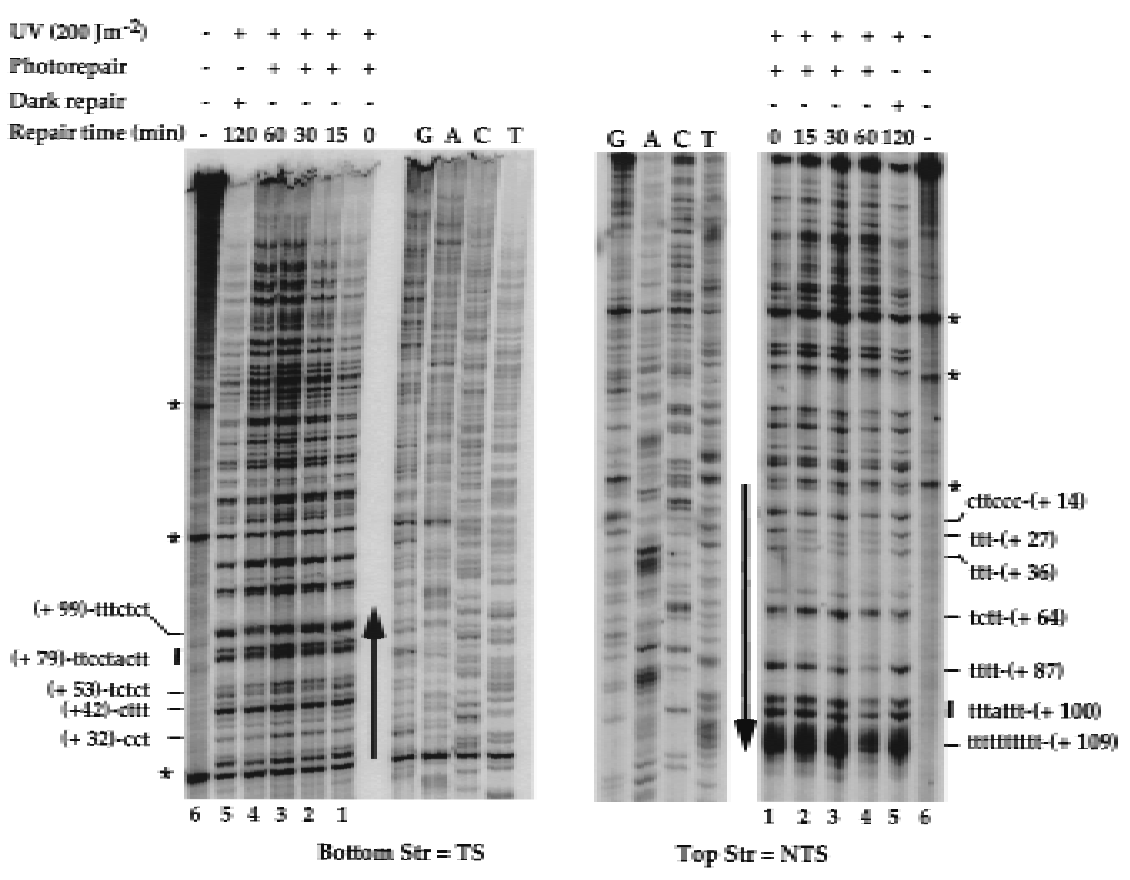

NER. These results point out the fact that the relationships between DNA repair and transcription seem to be confined to NER and RNAP II transcription. This emphasizes an important role of TFIIH in this connection, because it is the only RN AP II transcription factor that is essential for NER as well (Friedberg 1996b). The difference between yeast and mammalian cells may be the result of the behavior of the stalled RNAP III at the lesion. It is possible that the S. cerevisiae RN AP III ternary complex is more stable than the mammalian RNAP I or RNAP III ternary complexes, leading to a strong protection of the lesions and, thereby, to the repair obstruction in the TS.

The disappearance of the repair strand bias in the snr6 22 mutant was accompanied by a slight diminution of DNA repair rate at the NTS and a slight increase of repair efficiency in the TS, either by PR or by NER (Figs. $3 \mathrm{~B}$ and $4 \mathrm{~B})$. If we assume that slow repair of the TS is caused by blocked polymerases, then a release of polymerases by gene inactivation is expected to yield high repair rates equival ent to that of the NTS of the wildtype SNR6 gene, which was not observed. The intermediate level s of repair determined in snr6 22 may therefore be explained by the presence of nucleosomes and other DN A-binding factors in the snr $6 \Delta 2$ gene. These nucleosomes may not be positioned, because they were not detected in the snr6 22 in a previous study (M arsolier et al. 1995).

DNA repair and transcription: RNAP II and RNAP III systems

A major question that arises from these data is why the excision repair of the TS of RNAP III genes is not en- hanced as for RNAP II genes. Several reasons could expl ain the difference between RN AP II and RN AP III transcription regarding their relationships with DNA repair. First, RN AP III genes are very short, thus less frequently hit by DNA-damaging agents than the much longer RN AP II genes. Second, most of the RN AP III genes are multicopy (Percudani et al. 1997). Hence, very high doses of damaging agents would be required to inactivate all of them in the same time. Third, the half-life of RN AP III transcripts is rather long, therefore, cells may survive a long period without transcription of the damaged gene.

The NER is not strand-specific at the SUP4 intragenic box $\mathrm{A}$

N o N ER strand bias was observed in the SU P4 intragenic promoter element box $\mathrm{A}$, because the lesions of both strands were repaired with similar rates $(50 \%$ in $4 \mathrm{hr}$ ). This element is important for an accurate initiation of transcription, because it is one of the binding sites of TFIIIC complex (Geiduscheck and Kassavetis 1995). Unlike RNAP II promoters, this region is transcribed, and that raises an interesting question as to why TS and NTS are repaired with similar rates. If we admit that the re pair strand bias is the result of transcription, it is reasonable to assume that the absence of this strand bias is caused by the inhibition of RN AP III transcription. This inhibition could result from a very weak or no binding of TFIIIC on the UV-damaged box A element. The TFIIICbox $A$ complex is essential for transcription initiation, because it is TFIIIC that directs TFIIIB/RNAP III to the transcription start site (Geiduscheck and Kassavetis 1995; Zawel and Reinberg 1995). In a recent report, Tommasi et al. (1996) have shown that UV-induced PDs can 
inhibit the binding of some transcription factors (not TFIIIC) to their cognate elements in vitro.

\section{Mutagenesis is linked to nucl eotide excision repair}

It was reported previously that the mutagenesis frequency in the SUP4-o gene is higher in the TS than in the NTS (Armstrong and Kunz 1990, 1992). This higher mutagenesis could be explained by a lower DN A repair in the TS. The results presented in this paper support this hypothesis. In the box A region in which the mutagenesis is very low, the excision repair efficacy is the highest in this strand (Fig. 1B). Outside of this promoter region, however, in which slower repair was found, several mutagenesis hot spots were detected as in the pyrimidine clusters CTTT and СССТСТ at positions 54 and 89, respectively (Armstrong and Kunz 1990). Another example of higher mutagenesis in the TS was observed previously in mfd-deficient $\mathrm{E}$. coli lacking the TCR process (Oller et al. 1992). These results are in contrast with those of the TSs of RNAP II genes that are preferentially repaired and, consequently, show a lower mutagenesis as compared with the NTSs (Vrieling et al. 1989; M cGregor et al. 1991; Sage et al. 1993). In conclusion, these data establ ish a direct link between NER and mutagenesis, and indicate that RN AP III transcription is not coupled to NER and that, in opposition to RNAP II genes, it is the NTSS of RN AP III genes that are preferentially repaired.

\section{Materials and methods}

Yeast strains

FTY113: MAT $\alpha$, ade2-102, ura3-52, Iys2-801, his $\Delta 200$, leu $\Delta 1$, trp1 $\Delta 63 / p R S 314+U 6$ TRP1, SNR6; FTY 115: MAT $\alpha$, ade2-102, ura3-52, lys2-801, his $\Delta 200$, leu $\Delta 1$, trp1 $\Delta 63 /$ pRS314+U6 TRP1, snr6 $\Delta 2$ (Marsolier et al. 1995). AAY 1 and AAY 2 are rad1 $\Delta$ deletion strains derived from FTY 113 and FTY 115 , respectively. RAD1 deletion was generated by gene replacement technique (Rothstein 1983).

\section{Culture and UV irradiation of yeast cells}

Three liters of yeast cells were grown at $30^{\circ} \mathrm{C}$ in minimal me dium [ $2 \%$ dextrose, 0.67 yeast nitrogene base without amino acids (Difco)] (Sherman et al. 1986) supplemented with the appropriate amino acids to a final density of $\sim 10^{7}$ cell $\mathrm{s} / \mathrm{ml}$. The cells were then collected by centrifugation and resuspended in 1 liter water to a concentration of $1.5 \times 10^{7}$ to $3 \times 10^{7}$ cells $/ \mathrm{ml}$. Two hundred fifty-milliliter aliquots were transferred to a $22 \times 31.5-\mathrm{cm}$ plastic tray and UV-irradiated at room temperature with a dose of $200 \mathrm{~J} / \mathrm{m}^{2}$, with four Sylvania G15T 8 germicidal lamps (predominantly $254 \mathrm{~nm}$ ) at $1 \mathrm{~mW} / \mathrm{cm}^{2}$ (measured with a UVX radiometer UVP Inc., San Gabriel, CA).

\section{PR}

After UV irradiation, samples of 250-500 ml were photoreactivated in water with Sylvania type F15 T8/BLB bulbs (emission peak at $366 \mathrm{~nm}$ ) at $1.5 \mathrm{~mW} / \mathrm{cm}^{2}$ for $15-60 \mathrm{~min}$. Two hundred fifty-milliliters of cells were collected and chilled in ice.
Dark repair

After UV irradiation, minimal medium supplemented with the appropriate amino acids was added, and the cells were incubated at $30^{\circ} \mathrm{C}$ (in the dark) or under yellow light (Sylvania GE Gold fluorescent light) for various repair times. Repair was arrested by collecting cells (by centrifugation) and chilling them immediately in ice. All postirradiation steps were done in yellow light to prevent PR.

\section{DNA preparation and enzyme digestions}

Genomic DNA preparation was carried out with Qiagen tips and protocols (QIAGEN Genomic DNA Handbook). Pellets containing $1.5 \times 10^{9}$ to $3 \times 10^{9}$ cells were resuspended in $12 \mathrm{ml}$ of buffer Y 1 (1 M sorbitol, 0.1 м EDTA, $14 \mathrm{~mm} \beta M$ EtOH). One milligram per milliliter of Zymolyase was added $(100,000 \mathrm{U} /$ gram; Seikagaku Kogyo Co., Tokyo, Japan) and the cells were incubated at $30^{\circ} \mathrm{C}$ for $\sim 30 \mathrm{~min}$. Spheroplasts were harvested by centrifugation and resuspended in $15 \mathrm{ml}$ of buffer $\mathrm{G} 2(800 \mathrm{~mm}$ GuHCL, 30 mm EDTA, 30 mm Tris, 5\% Tween-20, 0.5\% Triton $\mathrm{X}-100$ at $\mathrm{pH}$ 8.0) supplemented with $100 \mathrm{ml}$ of proteinase $\mathrm{K}$ (10 $\mathrm{mg} / \mathrm{ml})$ and $100 \mathrm{ml}$ RN ase $A(10 \mathrm{mg} / \mathrm{ml})$. The suspension was then incubated for $2 \mathrm{hr}$ at $60^{\circ} \mathrm{C}$. Following the cell lysis, the cellular debris was spun down at $10,000 \mathrm{rpm}$ at $4^{\circ} \mathrm{C}$, and the supernatant was loaded on a pre-equilibrated Qiagen genomic tip for DNA purification. Pelleted by centrifugation at 10,000 rpm, DNA was dissolved in $200 \mathrm{ml}$ of TE at pH 8.0. DNA was then digested to completion with EcoRI (Böhringer M annheim), precipitated with ethanol, and redissolved in the same volume of TE (pH 8).

\section{Primer extension analysis}

Primer labeling and primer extension were done as described in Wellinger and Thoma (1996) with some modifications. The 10pmole primer was $5^{\prime}$ end-labeled with T4 nucleotide kinase (Biolabs) in the presence of 10 pmoles of radioactive $\left[\gamma^{-32}\right.$ P]ATP. The mixture was incubated for $30 \mathrm{~min}$ at $37^{\circ} \mathrm{C}$, the primer was then separated from the nonincorporated ATP with a G50 Sephadex column (Boehringer) and dissolved in an appropriate volume of TE (pH 8). Approximately 1-5 $\mu \mathrm{g}$ of EcoRI-digested genomic DN A was mixed with (1-5 ng) of radiolabel ed primer and was subjected to $30 \mathrm{cycles}$ of repeated denaturation $\left(94^{\circ} \mathrm{C}\right.$ for 45 $\mathrm{sec})$, annealing $\left(60^{\circ} \mathrm{C}\right.$ for $\left.4 \mathrm{~min}, 30 \mathrm{sec}\right)$ and extension $\left(72^{\circ} \mathrm{C}\right.$ for $2 \mathrm{~min}$ ) reactions, with 0.2 unit of Taq DNA polymerase (Perkin Elmer) for each reaction. The reaction products were ethanol precipitated and analyzed on a $4 \%$ or $5 \%$ polyacrylamide, urea $(50 \%)$ gel. The gels were then dried on a Whatman DE 81 paper and either autoradiographed (Fuji RX films) or analyzed with Phosphorlmager (Molecular Dynamics). DNA sequencing was done in parallel by use of Sanger chain termination method utilizing the same primers. The primers used were PAGE purified. For the SNR6 gene, top strand (no. 716), 5'-CGTACCATTGCATAGCTGTAACAATATTC-3'; bottom strand (no. 717a), 5'-TATATTGCTACCATGACTGTCTGAG-3'. For the SUP4 gene, top strand (no. 844), 5'-GCAATATGTCACAATTTGATAATA-3'; bottom strand (no. 845), 5'-CACTCTGAACCATCTTGGAAGGA-3'. For the SNR6 gene, the primers were chosen to anneal with regions that map outside of the SNR6 fragment present in the plasmid ( $M$ arsolier et al. 1995).

\section{Quantifications}

The sequencing gels were used to cal culate the rel ative repair of the lesions. First, a volume box was layed around each lesion. 
The value corresponding to the gel background was subtracted from the measured value. The obtained number was then divided by the value obtained by a volume box that covered the whole lane. This most accurately corrects for loading differences (see Figure 1A; Wellinger and Thoma 1997). The values obtained for the nonirradiated DNA were then subtracted to correct for unspecific background signal and Taq polymerase blockage. For standardization, the corrected values obtained at $t=0$ (no repair) were defined as $100 \%$ damage.

\section{Acknowledgments}

We are grateful to Dr. R.E. Wellinger, Dr. U. Schieferstein, and all the members of the $F$. Thoma group for their hel $p$ and interesting discussions. We thank Dr. U. Suter for continous support and Dr. C. Weissmann for access to the Phosphorlmager. This work was supported by grants from the Swiss N ational Science Foundation and by the ETH-Zürich, to (F.T.).

The publication costs of this article were defrayed in part by payment of page charges. This article must therefore be hereby marked "advertisement" in accordance with 18 USC section 1734 solely to indicate this fact.

\section{References}

Armstrong, J.D. and B.A. Kunz. 1990. Site and strand specificity of UVB mutagenesis in the SU P4-o gene of yeast. Proc. N atl. Acad. Sci. 87: 9005-9009.

- - - 1992. Excision repair influences the site and strand specificity of sunlight mutagenesis in yeast. Mutat. Res. 274: 123-133.

- - . 1995. Excision repair and gene orientation modulate the strand specificity of UV mutagenesis in a plasmid-borne yeast tRN A gene. Environ. Mol. Mutagen. 25: 12-22.

Bhatia, P.K., Z. Wang, and E.C. Friedberg. 1996. DN A repair and transcription. Curr. Opin. Genet. Dev. 6: 146-150.

Brow, D.A. and C. Guthrie. 1988. Spliceosomal RNA U 6 is remarkably conserved from yeast to mammals. Nature 334: 213-218.

- - - 1990. Transcription of a yeast U6 snRN A gene requires a polymerase III promoter element in a novel position. Genes \& Dev. 4: 1345-1356.

Chalut, C., V. M oncollin, and J.M. Egly. 1994. Transcription by RNA polymerase II: A process linked to DNA repair. BioEssays 16: 651-655.

Christians, F.C. and P.C. Hanawalt. 1993. Lack of transcriptioncoupled repair in mammalian ribosomal RNA genes. Biochemistry 32: 10512-10518.

Dammann, R. and G.P. Pfeifer. 1996. Lack of gene- and strandspecific DNA repair in RNA polymerase III-transcribed human tRN A genes. Mol. Cell. Biol. 17: 219-229.

Donahue, B.A., S. Yin, J.S. Taylor, D. Reines, and P.C. Hanawalt. 1994. Transcript cleavage by RN A polymerase II arrested by a cyclobutane pyrimidine dimer in the DNA template. Proc. Natl. Acad. Sci. 91: 8502-8506.

Drapkin, R., J.T. Reardon, A. Ansari, J.C. Huang, L. Zawel, K.J. Ahn, A. Sancar, and D. Reinberg. 1994. Dual Role of TFIIH in DNA excision repair and in transcription by RNA Polymerase II. Nature 368: 769-772.

Feaver, W.J., J.Q. Svejstrup, L. Bardwell, A.J. Bardwell, S. Buratowski, K.D. Gulyas, T.F. Donahue, E.C. Friedberg, and R.D. Kornberg. 1993. Dual roles of a multiprotein complex from S. cerevisiae in transcription and DN A repair. Cell 75: 13791387.

Friedberg, E.C. 1996a. Cockaine syndrome-a primary defect in
DNA repair, transcription, both or neither. BioEssays 18: $731-738$.

-_- 1996b. Relationships between DNA repair and transcription. Annu. Rev. Biochem. 65: 15-42.

Friedberg, E.C., G.C. Walker, and W. Siede. 1995. DNA repair and mutagenesis. ASM Press, Washington, DC.

Fritz, L.K. and M.J. Smerdon. 1995. Repair of UV damage in actively transcribed ribosomal genes. Biochemistry 34: 13117-13124.

Geiduscheck, E.P. and G.A. Kassavetis. 1995. Comparing transcriptional initiation by RNA polymerases I and III. Curr. Opin. Cell. Biol. 7: 344-351.

Goodrich, J.A. and R. Tjian. 1994. Transcription factors IIE and $\mathrm{IIH}$ and ATP hydrolysis direct promoter clearance by RN A polymerase II. Cell 77: 145-156.

Hanawalt, P.C. 1995. DNA repair comes of age. Mutat. Res. DNA Repair 336: 101-113.

Hernandez, N. 1993. TBP, a universal eukaryotic transcription factor. Genes \& Dev. 7: 1291-1308.

Knapp, G., J.S. Beckman, P.F. Johnson, S.A. Fuhrman, and J. A belson. 1978. Transcription and processing of intervening sequences in yeast tRN A genes. Cell 14: 221-236.

Kolsch, E. and P. Starlinger. 1965. A difference in the photoreactivation of UV-damage between genes in the repressed and genes in the de-repressed state. Z Vererbungsl. 96: 304-306.

Livingstone-Zatchej, M., A. Meier, B. Suter, and F. Thoma. 1997. RNA polymerase II transcription inhibits DN A repair by photolyase in the transcribed strand of active yeast genes. Nucleic Acids Res. 25: 3795-3800.

Marsolier, M.C., S. Tanaka, M. Livingstone-Zatchej, M. Grunstein, F. Thoma, and A. Sentenac. 1995. Reciprocal interferences between nucleosomal organization and transcriptional activity of the yeast SNR6 gene. Genes \& Dev. 9: 410-422.

McGregor, W.G., R.H. Chen, L. Lukash, V.M. Maher, and J.J. McCormick. 1991. Cell cycle-dependent strand bias for UVinduced mutations in the transcribed strand of excision re pair-proficient human fibroblasts but not in repair-deficient cells. Mol. Cell. Biol. 11: 1927-1934.

Oller, A.R., I.J. Fijalkowska, R.L. Dunn, and R.M. Schaaper. 1992. Transcription-repair coupling determines the strandedness of ultraviolet mutagenesis in Escherichia coli. Proc. Natl. Acad. Sci. 89: 11036-11040.

Percudani, R., A. Pavesi, and S. Ottonello. 1997. Transfer RN A gene redandancy and transcriptional selection in Saccharomyces cerevisiae. J. Mol. Biol. 268: 322-330.

Rothstein, R.J. 1983. One step gene disruption in yeast. Methods Enzymol. 101: 202-211.

Sage, E., E.A. Drobetsky, and E. M oustacchi. 1993. 8-M ethoxypsoralen induced mutations are highly targeted at crosslinkable sites of photoaddition on the non-transcribed strand of a mammalian chromosomal gene. EMBO J. 12: 397-402.

Sancar, A. 1996a. DNA excision repair. Annu. Rev. Biochem. 65: 43-81.

_- - 1996b. No "End of History" for photolyases. Science 272: 48-49.

Sancar, G.B. 1990. DNA photolyases-Physical properties, action mechanism, and roles in dark repair. Mutat. Res. 236: 147-160.

Sel by, C.P. and A. Sancar. 1993. M olecular mechanism of transcription-repair coupling. Science 260: 53-58.

_-_. 1994. Mechanisms of transcription-repair coupling and mutation frequency decline. Microbiol Rev. 58: 317-329.

Sel by, C.P., R. Drapkin, D. Reinberg, and A. Sancar. 1997. RN A polymerase II stalled at a thymine dimer: Footprint and effect on excision repair. Nucleic Acids Res. 25: 787-793.

Sherman, F., G.R. Fink, and J.B. Hicks. 1986. Laboratory course 
manual for methods in yeast genetics. Cold Spring Harbor Laboratory, Cold Spring Harbor, NY.

Suter, B., M. Livingstone-Zatchej, and F. Thoma. 1997. Chromatin structure modulates DNA repair by photolyase. EMBO J. 16: 2150-2160.

Svejstrup, J.Q., Z. Wang, W.J. Feaver, X. Wu, D.A. Bushnell, T. Donahue, E.C. Friedberg, and R.D. Kornberg. 1995. Different forms of TFIIH for transcription and DNA repair: HoloTFIIH and a nucleotide excision repairosome. Cell 80: 2128.

Tommasi, S., P.M. Swiderski, Y. Tu, B.E. Kaplan, and G.P. Pfeifer. 1996. Inhibition of transcription factor binding by ultraviolet-induced pyrimidine dimers. Biochemistry 35: 15693-15703.

Vos, J.M.H. and E.L. Wauthier. 1991. Differential introduction of DN A damage and repair in mammalian genes transcribed by RNA polymerase-I and polymerase-II. Mol. Cell. Biol. 11: $2245-2252$.

Vrieling, H., M.L. Vanrooijen, N.A. Groen, M.Z. Zdzienicka, J.W.I.M. Simons, P.H.M. Lohman, and A.A.V. Zeeland. 1989. DNA strand specificity for UV induced mutations in mammalian cells. Mol. Cell. Biol. 9: 1277-1283.

Wang, Z., J.Q. Svejstrup, W.J. Feaver, X. Wu, R.D. Kornberg, and E.C. Friedberg. 1994. Transcription factor $b(T F I I H)$ is re quired during nucleotide-excision repair in yeast. Nature 368: 74-76.

Wellinger, R.E. and F. Thoma. 1996. Taq DNA polymerase blockage at pyrimidine dimers. Nucleic Acids Res. 24: 15781579.

- - 1997. Nucleosome structure and positioning modulate nucleotide excision repair in the non transcribed strand of an active gene. EMBO J. 16: 5046-5056.

Wood, R.D. 1996. DNA repair in eukaryotes. Annu. Rev. Biochem. 65: 135-167.

Zawel, L. and D. Reinberg. 1995. Common themes in assembly and function of eukaryotic transcription complexes. Annu. Rev. Biochem. 64: 533-561.

Zawel, L., P.P. Kumar, and D. Reinberg. 1995. Recycling of the general transcription factors during RNA polymerase II transcription. Genes \& Dev. 9: 1479-1490. 


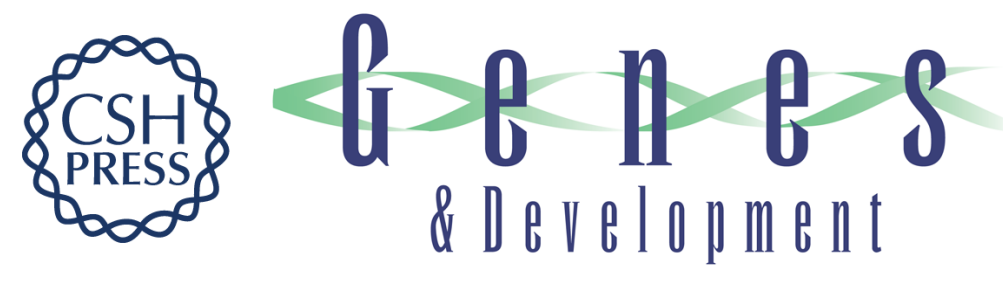

\section{Nucleotide excision repair and photolyase preferentially repair the nontranscribed strand of RNA polymerase III-transcribed genes in Saccharomyces cerevisiae}

Abdelilah Aboussekhra and Fritz Thoma

Genes Dev. 1998, 12:

References This article cites 44 articles, 15 of which can be accessed free at: http://genesdev.cshlp.org/content/12/3/411.full.html\#ref-list-1

License

Email Alerting Receive free email alerts when new articles cite this article - sign up in the box at the top Service right corner of the article or click here.

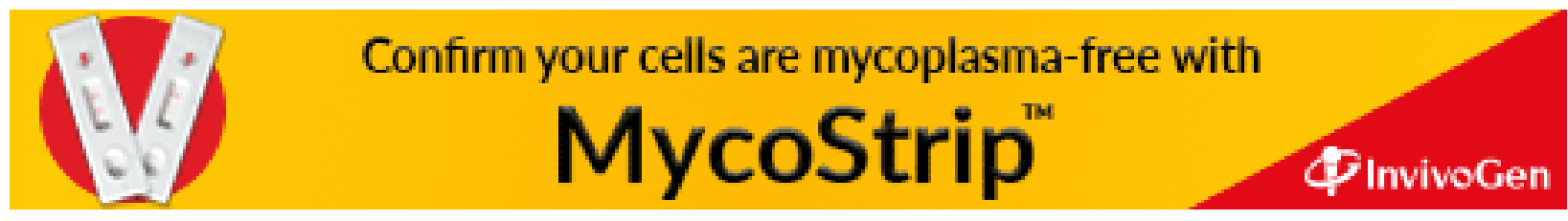

